\title{
Respon Kejadian Mesoscale Convective System dengan Gabungan Model Atmosfer-Oseanografi-Hidrodinamika Terhadap Potensi Gelombang Badai dan Inundasi di Area Pesisir Kepulauan Tanimbar
}

\author{
Khafid Rizki Pratama ${ }^{1}$, Ejha Larasati Siadari $\left.{ }^{2 *}\right)$, Bayu Edo Pratama $^{3}$ \\ ${ }^{I}$ Stasiun Meteorologi Mathilda Batlayeri, Kepulauan Tanimbar, Indonesia \\ ${ }^{2,3}$ Pusat Meteorologi Maritim, Badan Meteorologi Klimatologi dan Geofisika, Indonesia \\ *Email: ejhasiadari@gmail.com
}

\begin{abstract}
ABSTRAK
Interaksi laut dan atmosfer memegang peranan penting dalam pembentukan aktivitas konvektif di wilayah Kepulauan Tanimbar, interaksi kedua sistem tersebut dapat menimbulkan fenomena pola konvektif skala meso dan menyebabkan pengaruh yang signifikan terhadap pembentukan hujan dan angin kencang di wilayah tersebut. Sistem pergerakan dan peningkatan kecepatan angin akan berdampak pada naiknya gelombang air laut ke pesisir sehingga membentuk gelombang badai dan banjir pesisir (rob). Penelitian ini mengkaji bagaimana pengaruh Mesoscale Convective System (MCS) terhadap kejadian gelombang badai dan potensi banjir pesisir (rob) di Kepulauan Tanimbar selama tahun 2017 - 2018 dengan menggunakan gabungan model Coupled Ocean-Atmosphere Mesoscale Prediction System (COAWST) dan Advanced Circulation Model (ADCIRC) dengan tujuan untuk pengembangan sistem peringatan dini wilayah pelabuhan dan pesisir. Konsep model COAWST-ADCIRC dikopling secara langsung dengan OASIS3-MCT untuk parameter SST, spektrum gelombang laut dangkal dan sirkulasi angin. Respon kecepatan angin menunjukkan peningkatan sebesar $3.0 \mathrm{~m} / \mathrm{s}-4.5 \mathrm{~m} / \mathrm{s}$ dan energi gelombang laut meningkat hingga 0.4 - 0.6 meter serta level kenaikan air laut meningkat 0.3 meter. Verifikasi lanjutan dilakukan dengan data observasi pasang surut pola konstituens semi-diurnal dan citra satelit altimetri Jason 3, serta investigasi terhadap uji kualitas hasil model menggunakan pendekatan EnKF untuk mengetahui akurasi prediksi pola gelombang laut dangkal dan daerah terdampak inundasi.
\end{abstract}

Kata kunci: MCS, storm surge, inundasi, hidrodinamika

\begin{abstract}
Ocean and atmospheric interaction plays an important role in the formation of convective activities in the Tanimbar Islands, the interaction of the two systems can lead to the phenomenon of meso scale convective patterns and cause significant influence on the formation of rain and strong winds. The system of movement and increase in wind speed will have an impact on rising sea waves to the coast thus forming storm surge and coastal inundation. This study examines the effect of Mesoscale Convective System (MCS) on storm surge and coastal inundation potential in the Tanimbar Islands using a combination of Ocean-Atmosphere-Wave-Sediment Transport (COAWST) and Advanced Circulation Model (ADCIRC) with the aim of developing early warning system for the port and coastal areas. The concept of the COAWST-ADCIRC model is coupled directly with OASIS3-MCT for Sea Surface Temperatures, the spectrum of shallow water and wind circulation. The response of wind speed shows an increase of $3.0 \mathrm{~m} / \mathrm{s}-4.5 \mathrm{~m} / \mathrm{s}$ and ocean wave energy increases up to $0.4-0.6$ meters and the level of sea level rise increases by 0.3 meters. Further verification was carried out with tidal observation data of semi-diurnal constituent patterns and Jason 3 altimetry satellite data. While the investigation of model quality test using the EnKF approach to determine the accuracy of shallow water patterns and inundated affected areas predition.
\end{abstract}

Keywords: MCS, storm surge, inundation, hydrodinamics 


\subsection{LATAR BELAKANG}

Interaksi laut-atmosfer mempunyai peranan yang sangat penting terhadap dinamika dan kondisi baik perairan laut maupun lingkungan atmosfer, interaksi ini meliputi pertukaran momentum, energi dan massa. Perubahan kondisi atmosfer akan dapat mempengaruhi kondisi laut dan sebaliknya. Angin misalnya dapat menyebabkan terjadinya gelombang laut dan arus permukaan laut, curah hujan dapat mempengaruhi kadar salinitas air laut. Fenomena cuaca di laut memiliki peranan sangat vital dalam kegiatan kelautan seperti tinggi gelombang laut, sehingga informasi tentang kondisi gelombang yang mencakup tinggi, arah, variasi dan karakteristiknya harus terinformasi dengan baik. Salah satu fenomena yang terjadi dalam interaksi labilitas lautan dan atmosfer adalah siklon tropis, fenomena ini dapat menimbulkan dampak terhadap peningkatan kecepatan angin serta tinggi gelombang, bahkan fenomena ini dapat mengakibatkan naiknya tinggi muka air laut ke daerah pesisir yang dikenal dengan gelombang badai (storm surge). Gelombang badai adalah gelombang dengan panjang gelombang sampai beberapa kilometer yang dibangkitkan oleh badai (storm) dan penurunan tekanan atmosfer yang disebabkan suatu kejadian cuaca yang ekstrem. Pembangkit kekuatan gelombang badai bergantung pada tekanan udara di pusat badai siklon tropis yang sangat rendah sehingga menimbulkan kenaikan permukaan laut (upwelling) serta kekuatan wind-driven (TCWC Darwin, 2019). Naiknya permukaan air laut akibat melintasnya daerah tekanan atmosfer yang rendah akan membentuk gelombang yang menjalar ke luar daerah pembangkitnya dan ketika sampai di perairan pantai tinggi gelombangnya akan bertambah karena efek pendangkalan lautan dangkal. Gelombang badai merambat ke perairan dangkal, kecepatannya berkurang, panjang gelombangnya memendek, serta tingginya bertambah dan jika terjadi bersamaan dengan fase gelombang pasang surut pada kondisi air pasang tinggi (high tide) dapat menambah tinggi muka laut. Superposisi kedua jenis gelombang tersebut disebut gelombang badai pasang (storm tide) yang dapat mengakibatkan terjadinya gelombang ekstrem dengan tinggi dapat mencapai kurang lebih $2-5$ meter atau lebih. Kenaikan air laut akibat gelombang ekstrem dapat mengakibatkan banjir rob di daerah pantai jika tinggi muka laut melebihi tinggi daratan dan banjir tersebut dapat menghancurkan kehidupan sosial dan ekonomi penduduk. Di kawasan pantai, gelombang badai pasang dapat menyebabkan naiknya air laut ke darat dan menyebabkan banjir yang menggenangi daratan tersebut. Banjir yang disebabkan meluapnya air laut ini biasanya disebut rob yang dapat menyebabkan kelumpuhan perekonomian warga, kerusakan infrastruktur dan ekosistem sehingga perlu diwaspadai, serta mengakibatkan adanya pembentukan pola alun hingga daratan. Alun yang terbentuk tidak diakibatkan oleh gelombang namun adanya akibat angin kencang dan pasang laut dari terbentuknya siklon tropis dan berdampak menjalar hingga pesisir. Simulasi pemodelan adalah salah satu cara untuk mensimulasikan pengaruh siklon tropis dan Mesoscale Convective System (MCS) dalam pembentukan gelombang badai di wilayah Kepulauan Tanimbar. Pada penleitian ini penulis akan menggunakan coupled model. Model gabungan digunakan sebagai cara unutk mendapatkan sistem terdampak dari inundasi pesisir. Dengan memperhitungkan variasi parameter oseanografi seperti Sea Surface Temperature (SST) dan arus laut, serta parameter atmosfer seperti angin permukaan dan angin lapisan. Penelitian ini bertujuan untuk mengkaji pola kejadian dari MCS di wilayah pesisir Kepulauan Tanimbar yang sering terdampak dari siklon tropis sehingga menimbulkan gelombang badai dan bencana banjir pesisir (inundation) selama tahun 2017 - 2018 serta kajian sistem peringatan dini aktual sebagai upaya mengurangi resiko bencana dengan gabungan model COAWST-ADCIRC.

\subsection{Model COAWST-ADCIRC}

Model gabungan COAWST-ADCIRC adalah pemodelan pasang surut dan sirkulasi angin, analisis gelombang badai dan banjir, transportasi sedimen termasuk pengerukan dan pembuangan material, serta studi transportasi larva (ADCIRC, 2016). Untuk simulasi hidrodinamika, digunakan model terpilih yaitu dengan ADCIRC (Model 
Hidrodinamika Pantai dan Samudra). ADCIRC adalah sistem pemodelan menggunakan komputer untuk memecahkan waktu-independen, sirkulasi bebaspermukaan dan masalah transportasi dalam dua dimensi. Ini dikembangkan untuk model driven tidal dan sirkulasi angin di perairan pesisir (HydroQual Laboratories, 2015). ADCIRC dapat memperkirakan air pasang dan elevasi gelombang badai dan kecepatan sesuai dengan masing-masing node lebih besar. Model SWAN digunakan untuk menerapkan model atmosfer kedalam model lautan dangkal dan teknik finite element (unstructured mesh grid). Persamaan diformulasikan dengan menggunakan tekanan hidrostatik tradisional dan perkiraan boussinesq dan telah didikritasi di atmosfer dengan menggunakan metode finite element (FE) dan menggunakan metode finite difference (FD). ADCIRC dapat dijalankan baik sebagai model kedalaman twoDimensional Depth-Integrated (2DDI) atau sebagai model tiga dimensi (3D). Prediksi elevasi diperoleh dari solusi persamaan kontinuitas terintegrasi-kedalaman dalam bentuk Generalized Wave-Continuity Equation (GWCE).

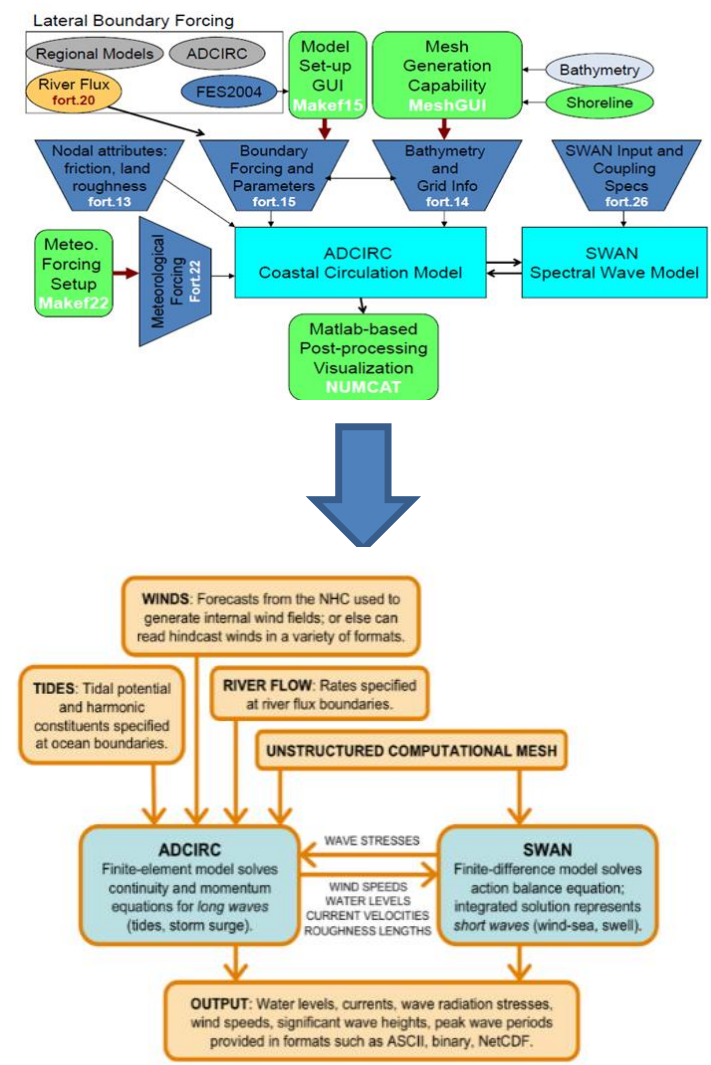

Gambar 1. Alur model COAWST-ADCIRC dengan model SWAN dan integrasi OASIS3MCT.

Velocity diperoleh dari solusi persamaan momentum 2DDI atau 3D. ADCIRC dapat dijalankan dengan menggunakan sistem koordinat Cartesian atau Sferis. GWCE diselesaikan dengan menggunakan matriks massa yang konsisten atau disamakan (melalui fungsi kompilator) dan skema waktu implisit atau eksplisit (melalui koefisien bobot waktu yang bervariasi). Formulasi yang disamakan dan sepenuhnya eksplisit ditentukan, tidak ada pemecah matriks yang diperlukan. Dalam semua kasus lain, GWCE dipecahkan dengan menggunakan pemecah iteratif Jacobi yang telah dikondisikan sebelumnya dari paket ITPACKV 2D. Persamaan momentum 2DDI disamakan dan tidak memerlukan pemecah matriks. Dalam 3D, difusi vertikal diperhitungkan secara implisit dan matriks massa vertikal tidak disamakan, sehingga memerlukan solusi dari matriks tri-diagonal kompleks di atas vertikal pada setiap horisontal.

\section{METODE}

Wilayah yang dikaji pada penelitian ini adalah Kepulauan Tanimbar yang merupakan gugusan Provinsi Maluku serta didominanasi oleh masyarakat yang tinggal dekat pesisir pantai. Kepulauan Tanimbar merupakan salah satu lokasi dekat dengan basin pertumbuhan siklon tropis dan low pressure yang terus meningkat setiap tahun dan berpotensi berdampak untuk masyarakat wilayah pesisir. Rentang waktu penelitian dilakukan berdasarkan pada dampak yang signifikan terjadi hingga menyebabkan bencana alam dan ketersediaan data tropical cyclone track dari Bureau of Meteorology (BOM) Australia dan CSIRO Australia serta Joint Tropical Warning Centre (JTWC) Best Track untuk siklon tropis dan Low Pressure dalam tahun 2017-2018.

Adapun data yang digunakan dalam penelitian ini meliputi data batimetri dari GEBCO dengan resolusi 30s, data Sea Surface Height (SSH) HYCOM-NCODA GOFS 3.1 dengan resolusi $0.080 \times 0.080$ derajat 
ftp://ftp.hycom.org/datasets/GLBv0.08/expt 92.9/ssh. Data shoreline dan coastline dari National Oceanic and Atmospheric Administration (NOAA-GSHHS) melalui website https://www.ngdc.noaa.gov. Data digunakan sebagai pembuatan unstructured mesh grid dan boundary dari garis pantai. Data Climate Forecast Reanalysis System (CFSR) dari NCEP-NOAA resolusi $0.5 \times 0.5$ derajat untuk jangka waktu tahun 2017 2018, data ini digunakan sebagai data masukan dalam model COAWST. Data water level dari Badan Informasi Geospasial (BIG) dan OSU Tidal Constituens wilayah titik stasiun pengamatan Pelabuhan Aktif Tanimbar Utara. Data altimetri dari satelit JASON-3 dengan resolusi $0.250 \times 0.250$ derajat dari tahun 2017 - 2018. Kalkulasi sistem gabungan model COAWST-ADCIRC mengasumsikan sistem integrasi kopling dengan OASIS3 - MCT yaitu dengan menggabungkan tiap parameter kopling dari unsur atmosfer dan lautan serta hidrodinamika sirkulasi angin dan gelombang laut. ADCIRC mengasumsikan sistem koordinat Cartesian dimana dimensi horisontal berada pada unit jarak yang sesuai dengan satuan gravitasi.

Formulasi koordinat Cartesian dalam Model ADCIRC yang dintegerasi melalui OASIS3 MCT ke dalam model COAWST sebagai berikut :

$$
\frac{\partial \mathrm{C}}{\partial t}+\frac{\partial U H}{\partial x}+\frac{\partial V H}{\partial y}=0
$$

Dan persamaan primitif momentum (dalam persamaan nonkonservatif)

$\frac{\partial U}{\partial t}+U \frac{\partial U}{\partial x}+V \frac{\partial U}{\partial y}-f V=-\frac{\partial}{\partial x}\left[\frac{p_{s}}{\rho_{0}}+g C-g(n+y)\right]+\frac{\tau_{g x}}{\rho_{o} H}-\frac{\tau_{b x}}{\rho_{0} H}+D_{x}-B_{x}$ $\frac{\partial U}{\partial t}+U \frac{\partial U}{\partial x}+V \frac{\partial U}{\partial y}+f U=-\frac{\partial}{\partial x}\left[\frac{p_{s}}{\rho_{0}}+g C-g(n+y)\right]+\frac{\tau_{g y}}{\rho_{o} H}-\frac{\tau_{b y}}{\rho_{o} H}+D_{y}-B_{y}$

Keterangan :

$$
\begin{aligned}
D_{x}= & \frac{\partial D_{u v}}{\partial x}+\frac{\partial D_{u v}}{\partial y}=\text { Dispersi momentum dalam } \mathrm{x} \\
D_{y}= & \frac{\partial D_{u v}}{\partial x}+\frac{\partial D_{u v}}{\partial y}=\text { Dispersi momentum dalam y } \\
B_{x}= & \int_{-h}^{C} b_{x} d z=\text { Gradien tekanan baroklinik secara vertikal } \\
\text { dalam x } & \text { vertikal dalam y } \\
B_{y}= & \int_{-h}^{C} b_{y} d z=\text { Gradient tekanan baroklinik secara } \\
\rho \quad= & \text { Waktu dan variasi kerapatan air secara spasial pada } \\
& \text { salinitas dan variasi temperature }
\end{aligned}
$$

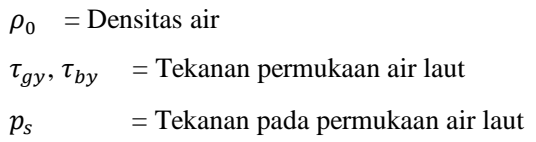

Kondisi lainnya adalah pengaturan terhadap sistem gridding permukaan yang hanya difokuskan pada gridding pesisir atau garis pantai (coastal area). Terdiri dari 1500 elemen dan 450 vortices, perbedaan 1500 elemen mengasumsikan grid terluar untuk titik tepi batas terbuka sebanyak 30 titik level konstituen, serta 450 vortices mengambil grid terdekat untuk tepi batas tertutup dengan garis pantai dan interpolasi batimetri. Kondisi nodal attribute di masukan sebagai inputan pembanding dari kondisi sea level dengan menggunakan data keluaran model Tidal Model Driver (TMD) dari data Oregon State University Tidal Data Inversion (OTIS). Penghubung grid menggunakan metode perhitungan nodal attributes dan kondisi kemiringan batimetri perairan Tanimbar Utara. Dan selanjutnya untuk verifikasi spasial dan statisik sederhana menggunakan data Jason 3.

\section{HASIL DAN PEMBAHASAN}

Dari hasil pantauan CSIRO Weather and Climate Research dan Bureau of Meteorology diketahui bahwa kenaikan frekuensi di wilayah Utara Australia meningkat sebesar lebih dari $30-40 \%$ (CSIRO and Bureau of Meteorology, 2015). Siklon tropis cenderung terbentuk antara $5^{\circ}$ $25^{\circ}$ lintang karena pada garis lintang ini parameter koriolis cukup untuk menghasilkan potensi dinamis suatu daerah konveksi (Gray, 1998). Parameter koriolis adalah fungsi garis lintang, tanpa penambahan koriolis di khatulistiwa dan penguatan lebih tinggi yang ditemukan pada garis lintang tinggi, perkembangan siklon tropis umumnya terjadi di dekat Khatulistiwa (Gray, 1975). Meskipun parameter koriolis lebih dominan untuk perkembangan siklon di lintang yang lebih tinggi di mana perairan laut yang lebih dingin dan wilayah dari ITCZ di lintang sekitar 250 lintang menekan perkembangan siklon tropis. Penyebab gelombang badai adalah tekanan atmosfer yang rendah dan angin di darat, dipengaruhi oleh batimetri dan 
batimetri laut. Komponen lainnya yang terjadi selama gelombang badai diilustrasikan pada poin penting yang terkait dengan definisi ini adalah bahwa tingkat badai pasang mungkin lebih rendah daripada tingkat pasang surut astronomi yang tinggi jika terjadi gelombang badai yang terjadi saat air surut.
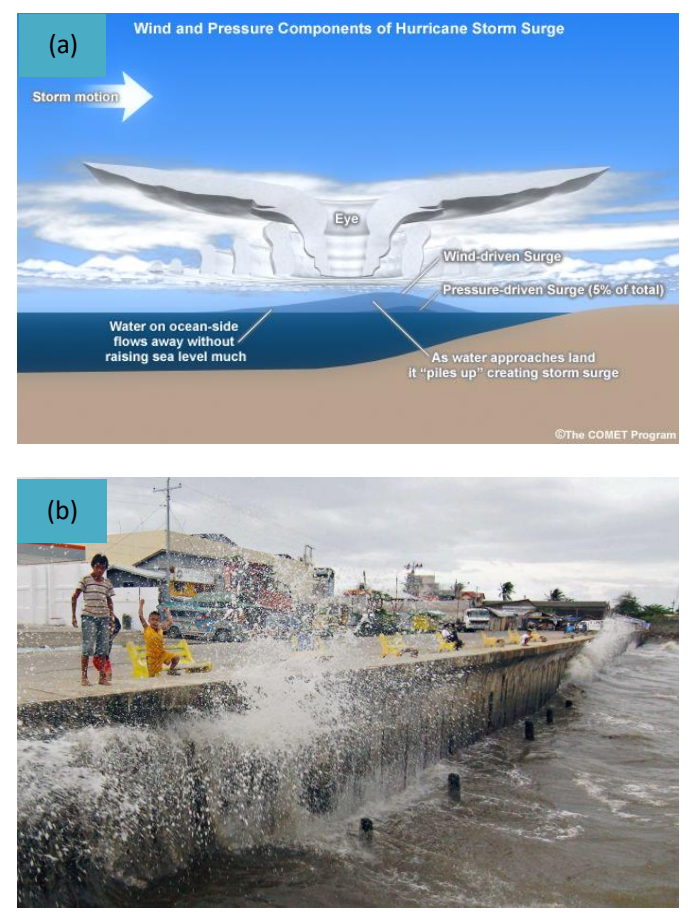

Gambar 2.Pola pembentukan (a) gelombang badai saat siklon tropis aktif 6 (b) pola gelombang badai yang terbentuk ketika menghantam pesisir.

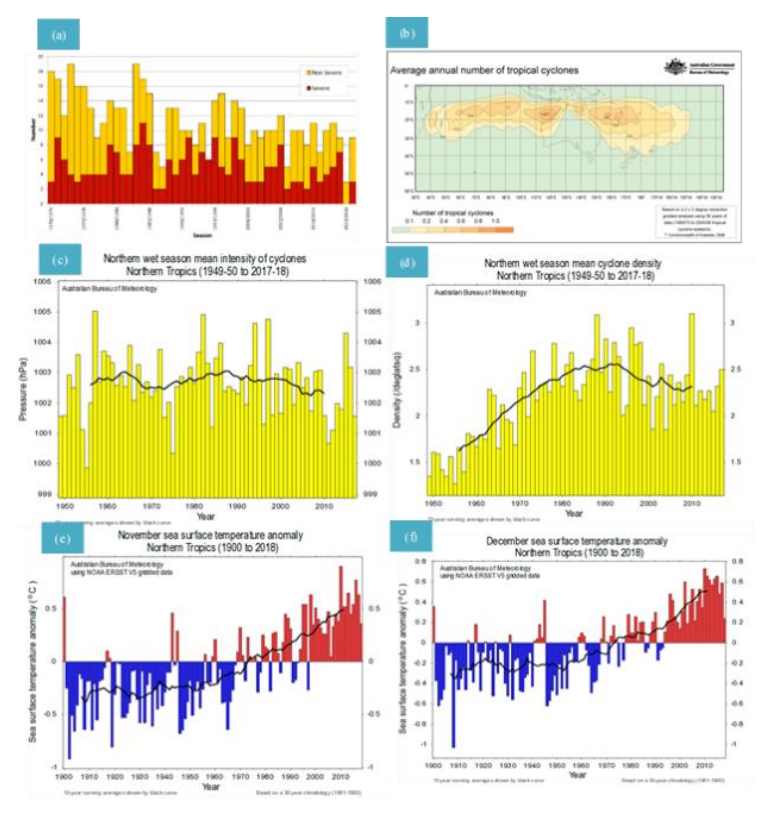

Gambar 3. Karakteritik frekuensi sistem konvektif dan siklon tropis wilayah utara Australia (a) Karakteristik frekuensi kejadian siklon tropis selama 20 tahun (b) Track rata-rata kejadian siklon tropis (c) Karakteristik kondisi tekanan udara saat siklon tropis aktif (d) Kondisi densitas saat siklon tropis aktif berdasarkan pengukuran citra satelit (e) Anomali SST dan (f) Anomali SST saat musim basah.

Hasil tersebut kemungkinan besar disebabkan oleh adanya kenaikan anomali SST dan kenaikan suhu subsurface lautan, yang merupakan unsur terbesar dalam pembentukan gangguan cuaca di lautan. Tabel grafik 3 memperlihatkan dalam kondisi real pembentukan siklon tropis dominan banyak terjadi di tahun 1985 - 1986 namun kondisi siklon tropis kuat hampir terjadi di sepanjang tahun 2011 dan terus mengalami peningkatan (Pratama, 2018). Sistem konvektif yang terjadi diwilayah Kepulauan Tanimbar dominan sering terjadi di bulan Januari-April, selain kondisi SST yang mengalami anomali, kondisi lain adalah tekanan udara rendah yang bertahan di wilayah Utara Australia. Pada gambar 3 diatas terlihat karakteristik dari pola sistem tekanan rendah semakin tahun semakin mengalami anomali penurunan, hal ini memperburuk kondisi sistem konvektif yang terjadi di pusat siklon. Mesoscale Convective yang terjadi sebelumnya dapat berkelanjutan menyebabkan siklon tropis atau Tropical Depression yang sangat mudah berpengaruh terhadap angin di laut dan kondisi gelombang laut secara langsung. Densitas yang terjadi dalam beberapa tahun menunjukkan peningkatan labilitas dan frekuensi kejadian sebanding dengan kejadian siklon tropis di wilayah utara Australia (Nothern Territory). Pola densitas menyebabkan kondisi udara labil dan siklus pertumbuhan sistem konvektif menjadi meningkat.

\section{Hasil Pemodelan COAWST-ADCIRC}

Pemilihan pemodelan yang berbasiskan Unstructured Mesh Grid (Triangular Network) dinilai sangat tepat, untuk kondisi 
tepi batas terbuka (open boundary) menggunakan data Sea Surface Height (SSH) dan data pengamatan tide gauge dengan konstituen M2 dan S2 level ketinggian muka air laut diatas 0 meter (WMO, 2011). Kondisi lainnya adalah pengaturan sistem gridding permukaan yang hanya difokuskan pada gridding pesisir atau garis pantai, terdiri dari 1500 elemen dan 450 vortices. Perbedaan 1500 elemen mengambil grid terluar untuk titik tepi batas terbuka sebanyak 30 titik level konstituen, serta 450 vortices menggunakan grid terdekat untuk tepi batas tertutup dengan garis pantai. Kondisi nodal attribute di masukan sebagai inputan pembanding dari kondisi water level pada saat kejadian siklon tropis dan sistem konvektif selama 2017 2018 dengan menggunakan data keluaran model Tidal Model Driver (TMD) dari data Oregon State University Tidal Data Inversion (OTIS). Penghubung grid menggunakan metode perhitungan nodal attributes dan kondisi batimetri lautan pesisir Tanimbar Utara.

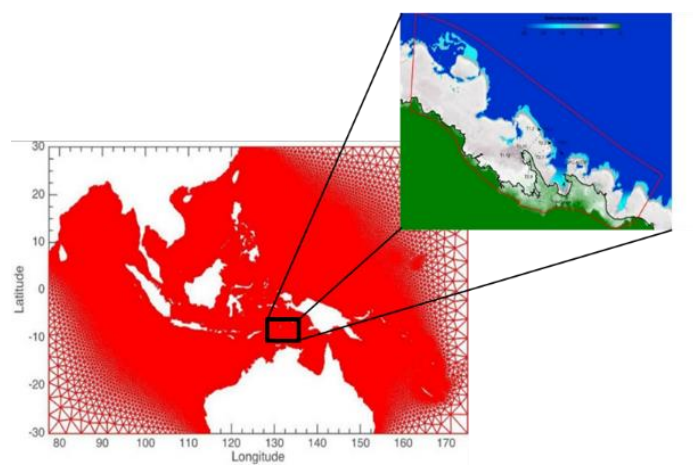

Gambar 4. Pola Unstructured Mesh Grid System wilayah Indonesia di nesting dalam wilayah Regional Kepulauan Tanimbar Pelabuhan Aktif Tanimbar Utara dengan open boundary Tidal Model Driver.

Berdasarkan simulasi dari model COAWST terlihat dari komposit ketinggian gelombang signifikan wilayah pesisir Tanimbar Utara pada saat fase sistem konvektif skala meso pembangkit pertumbuhan siklon tropis aktif bervariasi antara $4-7$ meter. Pada Gambar 2.4.a memperlihatkan pada fase Desember Januari - Februari (DJF) ketinggian gelombang laut signifikan yang menghantam pantai dapat menyebakan kondisi banjir pesisir. Pola konvektif dalam bulan DJF tidak terlalu tinggi, hal tersebut diakibatkan oleh pola transisi musiman yang masih aktif di wilayah Tanimbar sehingga anomali SST tidak terlalu signifkan. Sistem siklon tropis pada DJF juga lebih lemah dibandingkan pada fase musim Maret - April - Mei (MAM). Sedangkan pada gambar 5 terlihat pola current velocity pada fase DJF kecepatan arus terhadap kedalaman laut yang dalam lebih cepat merespon dibandingkan dengan pada kedalaman laut yang dangkal.

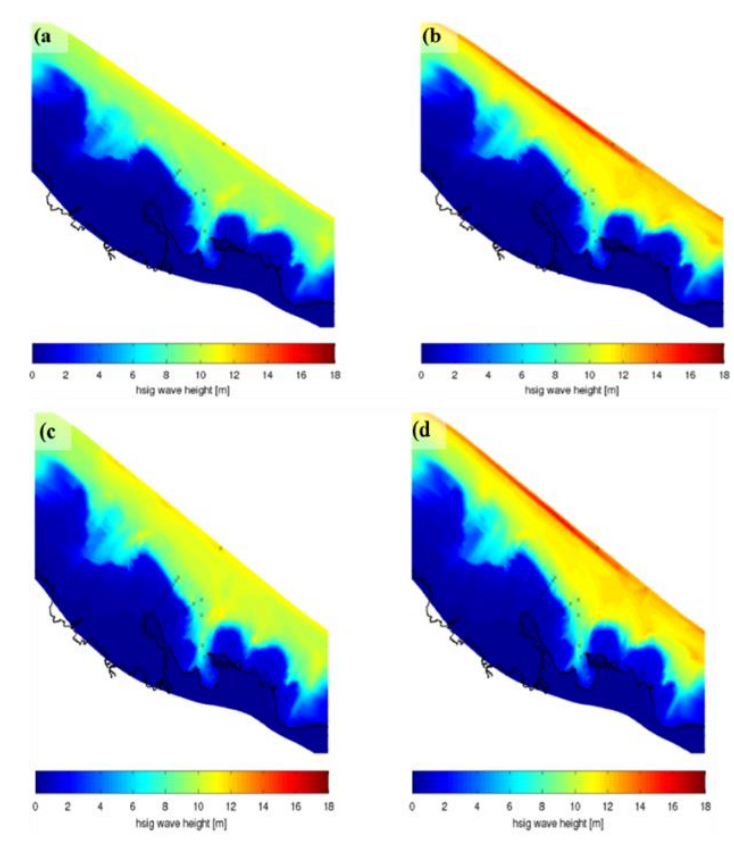

Gambar 5. Pola gelombang signifikan pesisir Tanimbar Utara saat sistem konvektif aktif selama tahun 2017 - 2018 keluaran model COAWST ADCIRC dengan gabungan parameter kopling dari OASIS3 - MCT dan parameterisasi standar (a) Fase Desember - Januari - Februari (DJF) (b) Fase Maret - April - Mei (MAM) (c) Fase Juli Juni - Agustus (JJA) (d) Fase September Oktober - November (SON). 

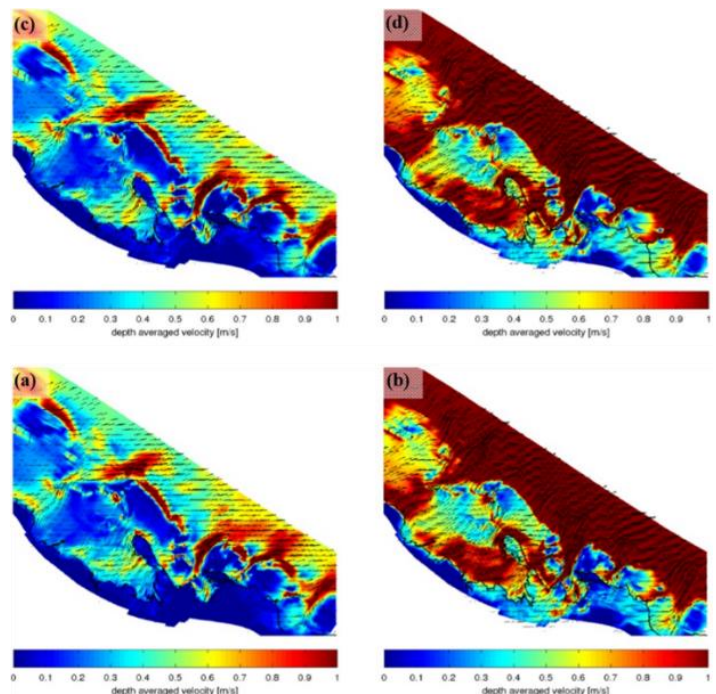

Gambar 6. Pola current velocity berdasarkan pada kedalaman pesisir Tanimbar Utara dengan kondisi saat sistem konvektif aktif (a) Fase Desember - Januari - Februari (DJF) (b) Fase Maret - April - Mei (MAM) (b) Fase Juni - Juli Agustus (JJA) (d) Fase September - Oktober November (SON).

Kecepatan arus yang terlihat sebesar maksimum $1 \mathrm{~m} / \mathrm{s}$ terjadi pada wilayah kedalaman pesisir yang dalam sedangkan pada wilayah dangkal hanya sebesar 0.1 hingga $0.7 \mathrm{~m} / \mathrm{s}$. Pola ini diakibatkan oleh adanya ada gesekan dasar laut dimana wilayah Tanimbar Utara lebih banyak terdapat karang dibandingkan pada kedalaman laut dalam adalah pasir.
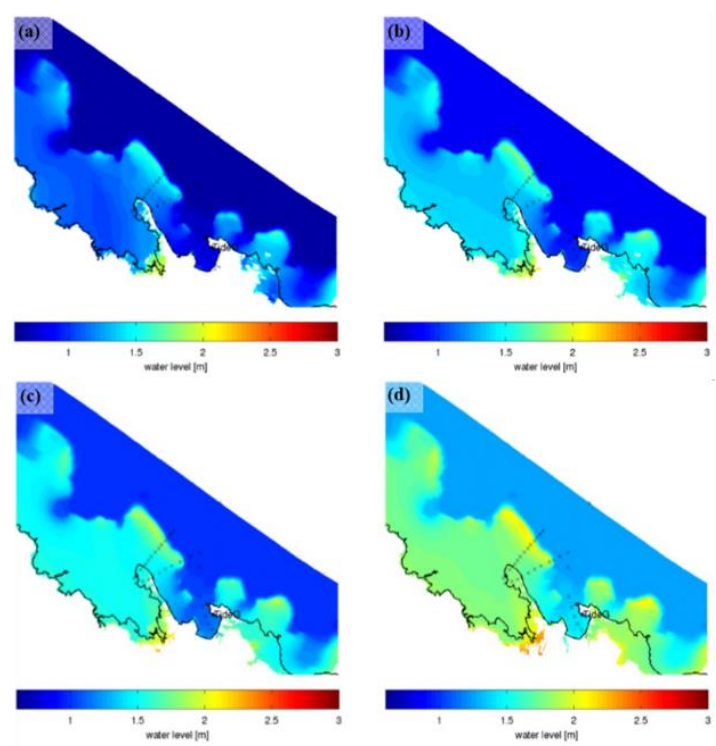

Gambar 7. Pola water level dan kombinasi inundasi pesisir Tanimbar Utara saat sistem konvektif aktif (a) Fase Desember - Januari Februari (DJF) (b) Fase Maret - April - Mei (MAM) (b) Fase Juni - Juli - Agustus (JJA) (d) Fase September - Oktober - November (SON).

Pada gambar 7 diatas terlihat variasi water level lebih banyak terjadi di wilayah Tanimbar bagian utara dimana merupakan wilayah dengan daratan paling rendah dan wilayah dengan datum tinggi air laut yang tinggi. Hasil tersebut sesuai dengan hasil model COAWST - ADCIRC, pola pada DJF memperlihatkan terjadi inundasi sebesar 1 1.5 meter, dimana wilayah Tanimbar Utara memiliki potensi banjir saat siklon tropis atau sistem konvektif aktif dengan intensitas kuat saat terjadi di wilayah tersebut. Sedangkan pada pola JJA potensi yang terkena saat siklon tropis aktif melintas sebesar $1.5-2.0$ meter.

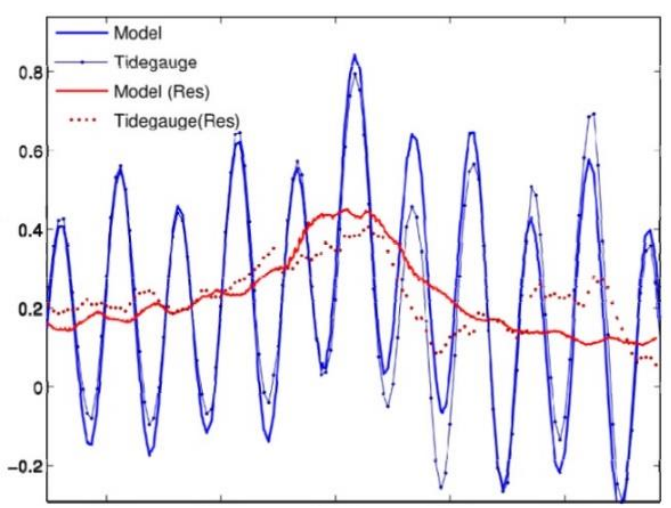

Gambar 8. Pola water level dan kombinasi inundasi pesisir Tanimbar Utara saat sistem konvektif aktif (a) Fase Desember - Januari Februari (DJF) (b) Fase Maret - April - Mei (MAM) (b) Fase Juni - Juli - Agustus (JJA) (d) Fase September - Oktober - November (SON)

Selanjutnya dilakukan verifikasi dengan metode sederhana dengan membandingkan pada tide gauge Pelabuhan Saumlaki dan Tidal Model Driver serta hasil keluaran model. Hasil model dan hasil tide gauge memperlihatakan kemiripan pola puncak dan lembah dimana merupakan fase pasang dan surut. Pola hasil model telah dikoreksi dengan Ensemble Kalman Filter, hasil model 
dengan tide gauge sebesar $20 \%$ dari hasil pengamatan tide gauge Pelabuhan Saumlaki. Hasil Model dengan tide gauge menggunakan Tidal Model Driver sebesar 30\%. Penyimpangan lebih besar terjadi pada TMD dengan hasil model. Dari hasil verifikasi tersebut juga diketahui bahwa terjadi kenaikan peningkatan energi gelombang yang ditunjang dengan naiknya pasang air laut selama tahun 2018.

\section{KESIMPULAN}

Respon kecepatan angin menunjukkan peningkatan sebesar $3.0 \mathrm{~m} / \mathrm{s}-4.5 \mathrm{~m} / \mathrm{s}$ dan energi gelombang laut meningkat hingga 0.4 - 0.6 meter serta level kenaikan air laut meningkat 0.3 meter. Hal tersebut dikarenakan potensi siklon tropis aktif menyebabkan kekuatan angin semakin cepat dan pola kecepatan angin yang membangkitkan arus dekat tepi pantai menjadi lebih dominan. Pola water level dari fase DFJ, MAM, JJA dan SON memiliki potensi besar ketika siklon tropis aktif kuat. Gelombang badai yang terbentuk di wilayah pantai akan menyebabkan banjir rob (inundasi). Hasil model COAWST ADCIRC cukup baik digunakan untuk kondisi pengembangan peringatan dini banjir pesisir. Perlu dilakukan kajian lebih lanjut terkait studi gelombang badai yang sesuai dengan data real time dari hasil pengamatan dan ketersediaan data best track tropical cyclone untuk sistem peringatan dini yang lebih aktual dan presisi.

\section{DAFTAR PUSTAKA}

ADCIRC, 2016. Advanced and Circulation Model for Oceanic, Coastal and Estuarine User Manual v52, University of North Carolina.

CSIRO and Bureau of Meteorology (BoM), 2015: Climate Change in Australia Information for Australia's Natural Resource Management Regions: Technical Report, CSIRO and Bureau of Meteorology, Australia.

Gray, W.M., 1975. Global view of Tropical Cyclone Genesis. Bulletin of the
American Meteorological Society, 56, 322.

Gray, W. M., 1998. The Formation of Tropical Cyclones. Meteorology and Atmospheric Physics, 67, 37-69.

HydroQual Laboratories, 2015, ADCIRC, http://www.hydroqual.com, diakses pada tanggal 27 Januari 2018.

NOAA, 2015. Tropical Cyclone Formation Regions, http://www.srh.noaa.gov/, diakses tanggal 12 Desember 2017.

Pratama, K. R. 2018, Karakteristik Gelombang Badai dan Gelombang Pasang Pasca Siklon Tropis Ernie dan Dahlia Berbasis Coupled Model ADCIRC-SWAN, Sekolah Tinggi Meteorologi Klimatologi dan Geofisika : Jakarta.

TCWC Darwin, 2019, Tropical Cyclone Climatology, http://www.bom.gov.au/cyclone/climato logy/trends.shtml, diakses pada tanggal 27 Januari 2018.

WMO, 2001. Guide to Marine Meteorological Services. WMO Document No. 471. Secretariat of the World Meteorological Organization, Geneva, Switzerland.

WMO, 2011. Guide to Storm Surge Forecasting. WMO Document No. 1076. Secretariat of the World Meteorological Organization, Geneva, Switzerland. 